И.А. Куян

\title{
К ВОПРОСУ ОБ ОПРЕДЕЛЕНИИ ПОНЯТИЯ И СОДЕРЖАНИЯ НАРОДНОГО СУВЕРЕНИТЕТА
}

\begin{abstract}
Аннотация: Статья посвящена проблеме определения понятия и содержания народного суверенитета. Рассматриваются основные элементы этого понятия: «суверенитет» и его определяющая составляющая «народный, народ». Особое внимание уделено исследованию категории «народ», различное толкование которой обусловливает, в первую очередь, проблемы определения содержания данного понятия. Исследуются основные формы общности народа: народ - совокупность граждан, народ - избирательный корпус, народ - население, народ - субъект конституционного права и конституционных отнотений. Рассматривается диалектика взаимосвязи между суверенитетом народа и правами человека. Автор приходит к выводу об универсальной политической правосубъектности народа, что выражается в его исключительном праве на самоопределение, а также о суверенитете как свойстве не только государства, но и народа.

Ключевые слова: Юриспруденция, народ, народный суверенитет, правосубъектность народа, право на самоопределение, носитель суверенитета, источник власти, субъект конституционного права, субъект конституиионно-правовых отношений, учредительная власть
\end{abstract}

ародный суверенитет является основоположным принципом, на основе которого развивается конституционно-правовая теория и практика государственного строительства современных демократических государств. Этот принцип находит отражение в конституционных актах ряда государств через утверждение народа источником государственной власти и носителем суверенитета, посредством закрепления основоположной роли народа в принятии конституции и/или учреждении государства. Ч.1 ст. 5 Конституции Украины утверждает, что народ является носителем суверенитета и единственным источником власти. Аналогичная норма закреплена в конституциях Российской Федерации (ст.3), Республики Беларусь (ст.3). В Преамбуле Основного Закона США, говориться о народе, который устанавливает Конституцию для государства. Также, о принятии Конституции народом говориться в Преамбуле Основного Закона Армении, а в ст. 2 утверждается принадлежность власти в Республике народу. Часть вторая статьи 20 Основного Закона ФРГ провозглашает, что вся государственная власть происходит от народа. Об учреждении Португальской Республики на основе народного суверенитета говорится в ст. 2 ее Конституции.

Даже при отсутствии в конституционных актах утверждения о принадлежности власти народу в государствах с монархической формой правления, демократический характер организации государственной власти проявляется через закрепление прав человека, институтов прямой демократии, парламентаризма, местного самоуправления, принципов верховенства права, разделения властей, что в принципе, является отражением народовластия, а также определенной степени и характера реализации принципа народного суверенитета.
Независимо от такой востребованости названного принципа конституционными актами разных государств и распространенности в мире государств с демократической организацией власти, его содержание по-разному раскрывается в конституциях и реализуется в практике государственного строительства современных государств. А исторический опыт развития идеи народного суверенитета, на пример, во Франции 18-19 века, казалось бы, вообще мог стать началом её забвения в мире. Очевидно, противоречивость реализации принципа и понятия народного суверенитета связана с различным его толкованием в юридической науке и неоднозначным отношением к нему различных юридических школ и течений - от полного отрицания ценности и оглашения его фикцией, до поднятия на пьедестал основоположного принципа правового, конституционного государства и природного права.

Современные энциклопедические словари толкуют народный суверенитет как «полновластие народа, владение народом социально-экономическими и политическими средствами для реального участия в управлении делами общества и государства» ${ }^{1}$. Подобно понятие народного суверенитета рассматривается в учебной юридической литературе. «Народный суверенитет, прежде всего, означает полновластие народа, то есть владение народом, который является единым источником власти политическими и социально-экономическими средствами для реального участия в реализации публичной, политической власти (государственной власти и местного самоуправления), в управлении государственными и общественными

\footnotetext{
${ }^{1}$ Большой юридический словарь. 3-е изд., доп.и перераб. / Под ред.проф. А.Я.Сухарева. - М.: ИНФРА-М, 2006. - У1. - С.727.
} 
делами»². «Суверенитет или полновластие народа - это владение им политическими и социально-экономическими средствами, всесторонне и полно обеспечивающими его реальное участие в управлении делами общества и государства ${ }^{3}$.

В научной юридической литературе сущность народного суверенитета сводят к таким основным положениям: народ является единственным источником верховной власти в государстве; публичная власть существует исключительно в его интересах; народу должно принадлежать верховное право решения наиболее важных вопросов государственной и общественной жизни, формирования органов публичной власти, которые будут реализовывать функцию политического управления, а также право контроля за их деятельностью. Названные положения дают основания исследователям толковать народный суверенитет как политико-юридическое свойство народа, означающее его способность и реальную возможность быть верховным и полновластным субъектом в решении наиболее важных вопросов внутренней и внешней политики в формах, не запрещенных конституцией и законами Украины ${ }^{4}$. Подобные определения, по нашему мнению, являются несколько противоречивыми. Во-первых, исходя из того, что раскрытие исключительно инструментальной сущности народного суверенитета (владение народом политическими и социально-экономическими средствами для реального участия в управлении делами государства и общества) не дает ответа на вопрос об основании такого владения, его объемах и практической реализации. Вовторых, учитывая семантику категории «суверенитет» как высшей, верховной власти, соединенной с прилагательным «народный», что должно было бы означать верховенство власти народа. Но тогда возникает вопрос о согласовании верховенства и ограничения форм решения вопросов внутренней и внешней политики (не запрещенные конституцией и законами).

Содержание понятия «народный суверенитет» формирует значение двух составляющих его терминов: «суверенитет» и его определяющая составляющая - «народный, народ», различное толкование которых и обусловливает в первую очередь, проблемы определения понятия и содержания данной категории. Суверенитет, как известно, характеристика, - свойство и признак государства, яв-

\footnotetext{
${ }^{2}$ Кравченко В.В. Конституційне право України: Навчальний посібник / В.В.Кравченко. - Вид. 3-тє, виправл. Та доповн. - К.: Атіка, 2004. - С.86.

3 Червонюк В.И. Конституционное право России: Учебное пособие. - М.: ИНФРА-М, 2004. - 432с.

${ }^{4}$ Людвік В.Д. Принцип народного суверенітету в історії політикоправової думки, теорії права та політичній практиці. Автореф. Дисс. канд..юрид.наук. 12.00.01. - Харківський нац. ун-т внутр. справ. - Х., 2009. - С.13.
}

ляющегося таковым (суверенным) в силу верховенства и независимости его власти. Таким образом, содержание понятия суверенитета государства определяют два основных признака: «верховенстсво государственной власти по отношению к другим социальным властям внутри страны и независимость государства по отношению к другим суверенным государствам вовне» ${ }^{5}$. Термин «народный» в этом словосочетании связывает названную характеристику государства с определенным субъектом и, тем самым, выражает содержание политической организации (государство народа) и политико-правовой статус человеческой обществости, - народа. С этой точки зрения природа народного сувернитета имеет комплексный характер. Такая двуединая его природа, думается, есть следствие исторических особенностей становления государства и развития его форм в мире, что связано с формированием идеи народовластия как антитезиса абсолютизму, а также с обогащением ее содержания в связи с формированием буржуазно-демократических и социалистических идей, активизацией народно- (национально-) освободительных движений и возникновением новых государств.

Вместе с тем, основная проблема в определении понятия и содержания народного суверенитета, как представляется, связана со сложностью толкования категории „народ“. Развитие идеи и понятия народного суверенитета в политико-правовой и конституционно-правовой мысли свидетельствует о том, что ценность его поддавалась сомнению многими учеными, в частности, в связи с произвольным толкованием понятия «народ», видения в нем не больше, чем абстракции или правовой фикции, «за которой в реальности стоят отдельные группы и личности, вследствие чего народ не способен быть субъектом власти и политики» ${ }^{6}$, наделения его унизительными характеристиками, отказа народу в статусе «субъекта права», непризнания его существования как реального явления. Это обусловлено целым рядом объективных и субъективных факторов: состоятием развития общества, уровнем культуры, образования, оценкой тех или иных форм политической организации общества, использованием разных теоретико-методологических подходов к исследованию соответствующих общественно-политических и юридческих явлений. Так В.М.Гессен отмечал, что в учении монархомахов 16 века народ - не сумма равноправных индивидов, а социально дифференцированное феодальное общество - совокупность сословных и территориально отделенных групп «чинов» и «провинций», что растворяют индивида. Господство большинства для монархо-

\footnotetext{
${ }_{5}^{5}$ Марченко М.Н. Государство и право в условиях глобализации. М.: Проспект, 2008. - С.69.

${ }^{6}$ Хевсаков В.В. Многонациональный народ Российской Федерации - субъект непосредственной демократии: проблемы теории // Государство и право, 2008. - № 2. - С.97.
} 


\section{Право и политика $1(157) \cdot 2013$}

махов - непостижимая идея ибо тисяча простых должны подчиняться тирану и только один знатный имеет право восстать против него. С этих двух элементов складывается народ: с одной стороны унижаемая монархомахами чернь, - пассивный элемент исторической жизни государства, с другой, - привелигированные сословные организации ее активный элемент. В результате у монархомахов народ как суверен, как верховная власть в государстве - это генеральные штаты, отдельные сословия и их члены, привилегированные города ${ }^{7}$ Владимир Соловьев ставил под сомнение принцип народовластия толкуя народ как сумму отдельных лиц (личностей), единство которых обусловлено случайным согласованием желаний и интересов, которого может и не быть ${ }^{8}$.

Только с расширением политических прав, особенно избирательного, на разные группы населения в юридической литературе начинает складываться идея народа как совокупности равноправных граждан, как политической целостности. Но не все так однозначно и в современной юридической литературе не существует общепринятого понимания понятия «народ». Замечу, что в ходе обсуждения этого вопроса в ООН не единожды отмечалась его сложность, и высказывалось сомнение по поводу возможности и необходимости выработки такого универсального определения, которое могло бы применяться в разных регионах мира и охватывало бы все потенциально возможные ситуации ${ }^{9}$ В свое время Международная комиссия юристов в связи с развитием событий в Восточном Пакистане рекомендовала для определения народов использовать такие критерии как общность истории, расовые и этнические, культурные и языковые, религиозные и идеологические связи, общее географическое местонаходжение, общая экономическая основа, достаточная численность данной общности ${ }^{10}$. Эти критерии, по нашему мнению, заслуживают внимания, но их применение не может быть однозначным для разных ситуаций и регионов.

Как философская категория, народ - это связанная одинаковым происхождением и языком культурная общность людей, которая является настоящим и единым

\footnotetext{
${ }^{7}$ Гессен В.М. Основы конституционного права (издание 2-е). Петроград, издание юридического книжного склада «Право», типо-литография общества А.Ф.Маркс, 1918г.( електронний ресурс. Адреса в інтернет: http: constitution.garant.ru/science-work/ pre-revolutionar/5148630/charter/2//).

${ }^{8}$ Соловьев В.С. Собрание сочинений и писем в 15 томах. Т.1. М., 1992. - C.273

9 Журек О.Н. Самоопределение народов в международном праве // Советское государство и право, 1990. - № 10. - С.99.

${ }^{10}$ Журек О.Н. Самоопределение народов в международном праве // Советское государство и право, 1990. - № 10. - С.99.
}

носителем объективного духа ${ }^{11}$. Ученые отмечают, что это понятие является собирательным, обобщающим и, тем самым, абстрактным ${ }^{12}$. В справочных юридических изданиях утверждается, что народ - это собирательное понятие, конструкция человеческого разума, которое включает в себя население данного государства (граждан, которые постоянно проживают в государстве, иностранцев и лиц без гражданства), создавшее единую социально-экономическую и политическую общность ${ }^{13}$. В научной литературе правильно подмечено, что теория еще не выработала единого подхода к определению понятия «народ», свидетельством чего есть такие его интерпретации: народ - граждане всех национальностей, которые проживают на территории данного государства; народ - совокупность физических лиц, подчиненных верховной власти; народ - совокупность отдельных лиц, которые входят в состав государства, совокупность членов государства, субъект и объект государственной власти; народ - стойкая общность людей, исторически сложившаяся на определенной территории, которая имеет общие относительно устойчивые особенности языка и культуры, а также осмысление своего единства среди других подобных образований, що отражается в самоназвании; народ - население государства ${ }^{14}$. Известный исследователь демократии Д.Сартори приводит шесть интерпретаций понимания народа: 1) народ - это буквально каждый; 2) народ - это неопределенное количество (очень много); 3) народ - это низший класс; 4) народ - это определенное неделимое единство, органическая целостность; 5) народ - это большая часть, которая выражена принципом абсолютного большинства; 6) народ - это большая часть, которая выражена принципом ограниченного (относительного) большинства ${ }^{15}$.

Еще с 18-19 веков термин «народ» наиболее часто употребляется в двух основных взаимосвязанных значениях: народ как совокупность всех граждан, - политическая общность и народ как совокупность избирателей (избирательный корпус) ${ }^{16}$. Можно сказать, что первым

\footnotetext{
11 Философский энциклопедический словарь. - М.: ИНФРА-М, 2001. - C.284.

12 Атаманчук Г.В. Теория государственного управления . Курс лекций. - М.:Юрид.лит., 1997. - С.283.

${ }^{13}$ Большой юридический словар (под. ред. А.В.Малько). - М.: Проспект, 2009.

${ }^{14}$ Людвік В.Д. Принцип народного суверенітету в історії політикоправової думки, теорії права та політичній практиці. Автореф. Дисс. канд..юрид.наук. 12.00.01. - Харківський нац..ун-т внутр. справ. - Х., 2009. - С.9.

${ }^{15}$ Джсованні Сарторі. Основи теорії демократії: народ і врядування / Демократія: Антологія / упоряд. О.Проценко. - К., 2005. - С.26.

${ }^{16}$ Шаповал В.Н. Сравнительное конституционное право. К.: ИД
} «Княгиня Ольга», 2007. - С.170. 
признаком в характеристике понятия «народ» является «общность» В этой связи возникает вопрос: что же объединяет разнообразие субъектов, их групп и интересов, что делает их общностью. Очевидно, что индивиды, связанные общим происхождением, языком, культурой, могут быть членами разных политических общностей в связи с тем, что проживают они в разных государствах или быть членами одной политической общности, хотя и отличаться от других ее членов в силу происхождения, родного языка и культуры (особенно в связи с интенсификацией миграционных процессов).

Вместе с тем, каждая подобная политическая общность имеет причины своего образования в самой себе. Это удовлетворение интересов членов этой общности (индивидуальных и групповых) черех реализацию интереса общности. Еще Цицерон, определяя категорию «народ» отметил, что это не любое объединение людей, а объединение, в основе которого общность интересов и согласованность в вопросах права ${ }^{17}$. Этот общий интерес лежит в основе совместной, общей воли индивидов и целого. Общая воля (интерес) не поглощает обсолютно индивидуальные воли (интересы). Они находятся в диалектической связи. Общая воля формируется благодаря индивидуальным волям, которые, в свою очередь, в ней находят основание и реализацию.

Как совокупность граждан всех национальностей, общность, объединенная правовой связью в государство, представлен народ в преамбуле Конституции Украины. При этом состав этой общности характеризуетсья полиэтничностью. Подобно народ характеризуется и в преамбуле Конституции Российской Федерации. Ч.2 ст.1 Конституции Азербайджана утверждает, что народ Азербайджана складывается из граждан Азербайджанской Республики, проживающих на ее территории и за границей и которые рассматриваются как подвластные государству и его законам. Характеристика народа как совокупности граждан находит отражение и в официальных названиях ряда государств: Алжирская Народная Демократическая Республика, Китайская Народная Республика, Корейская народно-демократическая Республика и др. В ст.2 Конституции Республики Македония даже утверждается, что суверенитет происходит от граждан и принадлежит гражданам. С точки зрения такой теоретической конструкции верховенство народа распадается на верховенство граждан, а суверенитет народа состоит из совокупности суверенитетов граждан, что, по существу, отрицает признак неделимости суверенитета. Подобная модель воспроизводит идею суверенитета личности и атомистический подход к формированию общей воли. Это тема для отдельного разговора.

${ }^{17}$ Шульженко Ф.П., Андрусяк Т.Г. Історія політичних і правових вчень. - К.: Юрінком Інтер, 1999. - 304c. - С.38.
Действительно, взаимосвязь категорий «народ» и «гражданин» как целого и части с точки зрения конституционного права кажется очевидной. Эта взаимосвязь выражается через определение гражданства как принадлежности лица к народу. Но народ не простая совокупность граждан, проживающих на определенной территории. Эта совокупность, а точнее сказать, общность образуется вследствие множества разнообразных социальных (политических, экономических, культурных) связей между индивидами, обусловленных стремлением к удовлетворению их общих и индивидуальных интересов в социальной, экономической, политической, культурной и т.д. сферах. Такие жизненноважные интересы не могут быть реализованы вне политической организации общества, главным инструментом которой выступает право. Соответственно, - индивиды, - носители разнообразных интересов не могут не быть субъектами права и участниками разнообразных правоотношений. Таким образом, народ предстает как организованная в государство общность граждан и взаимосвязей между ними, которая основывается на необходимости удовлетворения их общих и индивидуальных потребностей. При этом один и тот же социальный субъект - народ реализует разные роли: как элемент государства - политическая общность, как носитель публичной власти - общность юридическая, - субъект права. Эти две основные роли народа объединяются в одну функцию - он продуцирует публичную политическую власть.

Народ как совокупность избирателей, как избирательный корпус, - право- и дееспособная целостная политическая общность, субъекты которой (граждане государства) владеют политическими правами - еще одна ипостась народа, неотьмлемая от идеи народного суверенитета. Она находит отражение и в конституционных актах ряда государств через термины «народное волеизъявления», «народное голосование», «народный референдум» и др. Через подобные термины определяется правосубъектность народа как совокупность воль всех граждан государства, что основывается на правосубъектности гражданина.

В условиях мирного, эволюционного развития народный суверенитет невозможен в принципе, в обществе, члены которого лишены неотчуждаемых гражданских и политических прав и свобод. В этом состоит гуманистическая сущность идеи народного суверенитета. Диалектика взаимосвязи между суверенитетом народа и правами, свободами человека и гражданина состоит в том, что последние являются условием и средством обеспечения народовластия. Эта диалектика подтверждается историей развития теории прав человека и идеи суверенитета, теоретическим основанием которых была необходимость утверждения светского правового государства, идеал которого в своей основе требовал единого и одинакового для всех права. Позднее это требование расширилось 


\section{Право и политика $1(157) \cdot 2013$}

необходимостью подчинения праву и тех, кто призван реализовывать власть (органов государственной власти и их должностных лиц) и тем самым обеспечения равенства в отношениях не только граждан между собой, но и в отношениях «государство-гражданин». Политическая доктрина Французской революции утвердила в основе идеала правового госудрства два равных основания: идею народного суверенитета и идею неотчуждаемых прав человека. Поэтому, закономерно, что отсчет первого поколения прав человека ученые связывают с разрушением сословных рамок общества средних веков и установления хотя бы относительного юридического равенства. Первое поколение прав человека, как известно, составили неотчуждаемые личные (гражданские) и политические права: право на свободу совести и религии, мысли и слова, право на жизнь, на свободу и безопасность, право участвовать в государственных и общественных делах, право на судебную защиту. Политическим правам принадлежит особая роль, они выплывают из самой идеи народного суверенитета. Связь между народным суверенитетом и политическим правами, как правильно замечено Т.Шаповал, отражает сущность власти народа, участвовать в которой, реализуя соответствующие права, может каждый дееспособный гражданин ${ }^{18}$.

Как политическая и юридическая целостность народ провозглашается носителем суверенитета и/или источником власти в конституциях многих государств мира. Вместе с тем, в конституционных актах закрепляются и формы реализации власти народом (формы непосредственного народовластия и представительной демократии). Таким образом, статус носителя и /или источника суверенитета переводит народ из идеального в реальный, действующий субъект конституционно-правовых отношений.

Следует отметить, что статус народа как субъекта конституционного права и конституционно-правовых отношений не всегда однозначно воспринимался ученымиконституционалистами, что связано с различными подходами в определении субъектов власти в конституционной теории и практике, особенно советских времен.

В советском государственном праве этот вопрос был предметом многочисленных дискуссий, содержание которых было детально рассмотрено О.Е.Кутафиным ${ }^{19}$. Не останавливаясь основательно на содержании названных дискуссий, все же считаю необходимым обратить внимание на основные аргументы тех ученых, которые отказывали «народу» в статусе субъекта права. В частности, «если под «народом» по-

\footnotetext{
${ }^{18}$ Шаповал $T$. Народний суверенітет та політичні права і свободи (питання співвідношення) // Право України, 2008. - № 2. - С. 9-12. - C.12

${ }^{19}$ Кутафин О.Е. Избранные труды: в 7 томах. Том 1. Предмет конституционного права: монография. - Москва: Проспект, 2011.
} - 448c. - C.316-325. нимать некую историческую общность, которая изменяется в зависимости от заданий развития, решаемых обществом в данный период, то такая общность не является субъектом права, поскольку ее деятельность по преобразованию общества не связана юридическими нормами». Или «народ как субъект общественных отношений создает всю юридическую надстройку, но сам не владеет правосубъектностью, поскольку учитывая его огромную социальную роль, правовые границы уменьшают его суверенитет». Подобные точки зрения разделяли ряд советских ученых, в частности, В.Т.Кабишев, О.О.Миронов, А.В.Мицкевич ${ }^{20}$. А.В.Мицкевич, например, считал, что народ является творцом новых общественных отношений, а непосредственными субъектами разных правоотношений в обществе и от его имени выступают разнообразные организации. По мению ученого, народ не может быть ни обязанной, ни управомоченной стороной в правоотношениях, поскольку не может быть другой, равной ему по социальной значимости стороны, перед какой он мог бы нести юридические обязанности, а сам с собой народ не может вступать в правоотношения; поэтому субъектами права от имени народа выступают государство, его органы, общественные организации ${ }^{21}$. Вместе с тем, подобные точки зрения не были доминирующими и ряд ученых, в частности, В.Ф.Коток, О. Е. Кутафин, «защищали» статус народа як суб'єкта права. Но сам характер дискуссий в то время, сегодня кажется несколько парадоксальным. С одной стороны, провозглашаемое всевластие народа, а с другой,--всевластие ограничено мега ролью, что не требует непосредственных прав. Выглядит как некий юридический нонсенс, поскольку у власти, не имеющей прав, остается только сила.

В современном конституционном праве Украины (и России) считается общепризнанным, что народ является субъектом права, в первую очередь, конституционного, и может выступать как субъект определенных конституционно-правовых отношений. Непосредственные права и обязанности народа (нации) как политической целостности закрепляются в конституциях многих современных государств. В конституционных актах ряда государств уже в преамбулах констатируется реализация народом (нацией) право на самоопределение и создание собственного государства (США, Литва, Латвия, Словакия, Франция). В основных законах некоторых государств права народа сформулированы обобщенно или определяются детализировано, особенно в вопросах, решаемых на референдумах или предусматривается делегирование прав народа органам государственной власти. Так, в

\footnotetext{
${ }^{20}$ См.: Кабышев В.T., Миронов О.О. Категория «народ» в советском конституционном законодательстве // Правоведение, 1969. № 4. С.36-41; Мицкевич А.В. Субъекты советского права. М., 1962.

${ }^{21}$ Кабышев B.T., Миронов О.О. Категория «народ» в советском конституционном законодательстве // Правоведение, 1969. № 4. C.40-41.
} 
Конституции Азербайджанской Республики закреплено право народа свободно и независимо определять свою судьбу и учреждать для себя форму правления (ст.2). В Конституции Боливии утверждается, что реализация суверенитета делегируется органам законодательной, исполнительной и судебной власти (ст.2). Из содержания статьи 5 Конституции Украины, провозглашающей исключительное право народа определять и изменять конституционный строй, выплывает исключительное право народа на всеукраинском референдуме решать вопрос об изменении территории Украины (ст.73). Если под конституционным строем понимать определенную форму организации государства и общества, которая установлена в конституционном порядке ${ }^{22}$, то право народа определять и изменять форму организации государства и общества предполагает и право определения содержания, самой сущности государства и выбор форм такого определения. Сказанное (во всяком случае, применительно к Украине) позволяет сделать вывод о том, что как публично-правовой субъект народ Украины владеет универсальной политической правосубъектностью, которая выражается в его исключительном праве на самоопределение.

В ст.1 Международного пакта о гражданских и политических правах прямо определяется, что все народы имеют право на самоопределение, в силу которого они свободно устанавливают свой политический статус и свободно обеспечивают своё экономическое, социальное и культурное развитие. Реализация народом права на самоопределение предполагает свободное установление им своего политического статуса, как во внутригосударственных, так и в международных отношениях. В первом случае речь может идти преимущественно о праве выбора моделей (систем) политического, экономического, культурного развития. Во втором, - речь идет о праве народа свободно выбирать свой статус в международных отношениях. Вопрос реализации народом своего внешнего (международного) статуса требует отдельного рассмотрения. Здесь же отметим, что касательно права народа на выбор внутриполитического статуса, в наиболее общем смысле можно вести речь о его праве на самоуправление. Возможность обретения государственного суверенитета, как точно подмечено Л.Т.Кривенко, - одно из ключевых положений верховенства народа ${ }^{23}$. Такое право не исчерпывается одноразовым актом реализации учредительной

${ }^{22}$ Конституційне право України. Академічний курс: Підручник: У 2т. - Т.2 / За загальною редакцією Ю.С.Шемшученка. - К.: ТОВ «Видавництво «Юридична думка», 2008. - 800с. - С.11

${ }^{23}$ Конституційно-правові форми безпосередньої демократії в Україні: проблеми теорії і практики. До 10-ї річниці незалежності України / В.Ф.Погорілко, М.І.Ставнійчук, Н.І.Руда, Л.Т.Кривенко, О.В.Батанов та ін. - К.: Інститут держави і права ім. В.М.Корецького НАН України, 2001. - 356c. - С.109. власти путем принятия, одобрения или утверждения конституции. Оно предусматривает постоянную реализацию народом своего политического статуса в определенных им самим формах. Народ может быть лишен реальной власти, но его право на власть является бесспорным и неотчуждаемым с силу своей естественности. Основу права народа на власть составляет его неотъемленое право на сопротивление угнетению. В этом, по моему мнению, состоит основное содержание идеи народного суверенитетета. Народ имеет право распоряжаться своей судьбой: определять и изменять конституционный строй. В этом и состоит верховенство власти народа. Верховное право народа на определение содержания и форм своей организации отрицает любую его зависимость в этом вопросе от кого-либо.

Таким образом, народный суверенитет предполагает верховенство, независимость и отсутствие ограничения власти народа любыми другими видами власти (или субъектами). Формально, власть народа ограничена индивидуальными правами и свободами человека и гражданина. Содержательно, право политической общности не может не основываться не неотчуждаемости и нерушимости прав и свобод ее членов. В этом состоит «конфликтность» теории народного суверенитета, ибо в ее основе соединены два диаметрально противоположных начала - принципа: индивидуализм и коллективизм. Усиление каждого отдельного из них в процессе практической реализации неизменно приводит к искривлению идеи и отдалению от идеальной модели. А обеспечение их динамического равновесия является целью и задачей теории и практики современного конституционализма.

Неограниченность власти народа означает невозможность ограничения, - неотчуждаемость, неделимость, безусловность его права на власть, что по смыслу Конституции Украины означает недопустимость ограничения права народа определять и изменять конституционный строй.

Исходя из вышеизложенного, можна утверждать, что сущность народного суверенитета состоит в верховенстве, независимости и неограниченности права народа на власть, что позволяет высказать предположение о суверенитете как свойстве не только государства, но и народа.

При этом верховенство власти народа имеет не только организационно-правовой аспект, но и функциональный, - как «верховенство в решении конкретных вопросов организации своей жизни, - общественного и государственного строя, основных направлений развития внутренней и внешней политики, экономических установлений и осуществлении полного и всестороннего контроля за деятельностью государственных органов и государства в целом $»^{24}$, а также и правовий аспект, как

${ }^{24}$ Марченко М. Н. Проблемы теории государства и права: учеб. М.: ТК Велби, Изд-во Проспект, 2007. - 768с. - С. 137. 


\section{Право и политика $1(157) \cdot 2013$}

исключительное, неотчуждаемое, неделимое и безусловное право народа на власть.

С такой точки зрения любые концептуальные ограничения власти народа вроде идеи «народ - орган государства», «народ правовочен действовать исключительно в конституционно определенных формах», «народ управляет только через ораны государственной власти» кажутся искусственными не только с точки зрения теоретического моделирования, но и в силу того, что реальная способность народа учреждать собственную государственность или изменять конституционный строй не раз подтверждалась, и, думается, будет подтверджаться, в политической истории мира.

Рассмотренное не исчерпывает вопросы определения понятия и содержания народного суверенитета, а подтверждает необходимость дальнейшей разработки этой проблематики.

\section{Библиография:}

1. Большой юридический словарь. 3-е изд., доп.и перераб. / Под ред.проф. А.Я.Сухарева. - М.: ИНФРА-М, 2006. - У1, 858c. - (Б-ка словарей «ИНФРА-М»).

2. Кравченко В.В. Конституційне право України: Навчальний посібник / В.В.Кравченко. - Вид. 3-тє, виправл. Та доповн. - К.: Атіка, 2004. - 512c.

3. Червонюк В.И. Конституционное право России: Учебное пособие. - М.: ИНФРА-М, 2004. - 432с.

4. Людвік В.Д. Принцип народного суверенітету в історії політико-правової думки, теорії права та політичній практиці. Автореф. Дисс. канд..юрид.наук. 12.00.01. - Харківський нац. ун-т внутр.справ. - Х., 2009. - 18c.

5. Марченко М.Н. Государство и право в условиях глобализации. - М.: Проспект, 2008. - 400с.

6. Хевсаков В.В. Многонациональный народ Российской Федерации - субъект непосредственной демократии: проблемы теории // Государство и право, 2008, № 2, C. 96-100.

7. Гессен В.М. Основы конституционного права (издание 2-е). - Петроград, издание юридического книжного склада «Право», типо-литография общества А.Ф.Маркс, 1918г. URL http: constitution.garant.ru/ science-work/pre-revolutionar/5148630/charter/2 (Дата обращения 15.12.2011г).

8. Соловьев В.С. Собрание сочинений и писем в 15 томах. Т.1. М.: ПАИМС, Логос, Либрис, 1992. - 416c.

9. Журек О.Н. Самоопределение народов в международном праве // Советское государство и право, 1990. - № 10. - С.98-108.

10. Философский энциклопедический словарь. - М.: ИНФРА-М, 2001. - 516c
11. Атаманчук Г.В. Теория государственного управления . Курс лекций. - М.:Юрид.лит., 1997. - 400с.

12. Большой юридический словар (под. ред. А.В.Малько). - М.: Проспект, 2009-650с.

13. Джованні Сарторі. Основи теорії демократії: народ і врядування / Демократія: Антологія / упоряд. О.Проценко. - К., 2005. - 340с.

14. Шаповал В.Н. Сравнительное конституционное право. - К.: ИД «Княгиня Ольга», 2007. - 416с.: ил.

15. Шульженко Ф.П., Андрусяк Т.Г. Історія політичних і правових вчень. - К.: Юрінком Інтер, 1999. - 304c.

16. Шаповал Т. Народний суверенітет та політичні права і свободи (питання співвідношення) // Право України, 2008. - № 2. - С. 9-12.

17. Кутафин О.Е. Избранные труды: в 7 томах. Том 1. Предмет конституционного права: монография. Москва: Проспект, 2011. - 448c.

18. Кабышев В.Т., Миронов О.О. Категория «народ» в советском конституционном законодательстве // Правоведение, 1969. № 4. С.36-41.

19. Мицкевич А.В. Субъекты советского права. М.: Госюридиздат, 1962.-211c.

20. Конституційне право України. Академічний курс: Підручник: У 2т. - Т.2 / За загальною редакцією Ю.С.Шемшученка. - К.: ТОВ «Видавництво «Юридична думка», 2008. - 800с.

21. Конституційно-правові форми безпосередньої демократії в Україні: проблеми теорії і практики. До 10-ї річниці незалежності України / В.Ф.Погорілко, М.І.Ставнійчук, Н.І.Руда, Л.Т.Кривенко, О.В.Батанов та ін. - К.: Інститут держави і права ім. В.М.Корецького НАН України, 2001. - 356с.

22. Марченко М. Н. Проблемы теории государства и права: учеб. - М.: ТК Велби, Изд-во Проспект, 2007. $-768 \mathrm{c}$.

\section{References (transliteration):}

1. Kravchenko V.V. Konstitutsiyne pravo Ukraïni: Navchal'niy posibnik / V.V.Kravchenko. - Vid. 3-te, vipravl. Ta dopovn. - K.: Atika, 2004. - 512s.

2. Chervonyuk V.I. Konstitutsionnoe pravo Rossii: Uchebnoe posobie. - M.: INFRA-M, 2004. - 432s.

3. Lyudvik V.D. Printsip narodnogo suverenitetu v istorii politiko-pravovoï dumki, teoriï prava ta politichniy praktitsi. Avtoref. Diss. kand..yurid.nauk. 12.00.01. Kharkivs'kiy nats. un-t vnutr.sprav. - Kh., 2009. - 18s.

4. Marchenko M.N. Gosudarstvo i pravo v usloviyakh globalizatsii. - M.: Prospekt, 2008. - 400s.

5. Khevsakov V.V. Mnogonatsional'nyy narod Rossiyskoy Federatsii-sub'ekt neposredstvennoy demokratii: problemy teorii // Gosudarstvo i pravo, 2008, № 2, S. 96-100. 
6. Gessen V.M. Osnovy konstitutsionnogo prava (izdanie 2-e). - Petrograd, izdanie yuridicheskogo knizhnogo sklada «Pravo», tipo-litografiya obshchestva A.F.Marks, 1918g. URL http: constitution.garant.ru/science-work/prerevolutionar/5148630/charter/2 (Data obrashcheniya 15.12.2011g).

7. Solov'ev V.S. Sobranie sochineniy i pisem v 15 tomakh. T.1. M.: PAIMS, Logos, Libris, 1992. - 416s.

8. Zhurek O.N. Samoopredelenie narodov v mezhdunarodnom prave // Sovetskoe gosudarstvo i pravo, 1990. - № 10. S.98-108.

9. Atamanchuk G.V. Teoriya gosudarstvennogo upravleniya . Kurs lektsiy. - M.:Yurid.lit., 1997. - 400s.

10. Dzhovanni Sartori. Osnovi teoriï demokratiï: narod i vryaduvannya / Demokratiya: Antologiya / uporyad. O.Protsenko. - K., 2005. - 340s.

11. Shapoval V.N. Sravnitel'noe konstitutsionnoe pravo. - K.: ID «Knyaginya Ol'ga», 2007. - 416s.: il.
12. Shul'zhenko F.P., Andrusyak T.G. Istoriya politichnikh i pravovikh vchen'. - K.: Yurinkom Inter, 1999. - 304s.

13. Shapoval T. Narodniy suverenitet ta politichni prava $i$ svobodi (pitannya spivvidnoshennya) // Pravo Ukraïni, 2008. - № 2. - S. 9-12.

14. Kutafin O.E. Izbrannye trudy: v 7 tomakh. Tom 1. Predmet konstitutsionnogo prava: monografiya. Moskva: Prospekt, 2011. - 448s.

15. Kabyshev V.T., Mironov O.O. Kategoriya «narod» v sovetskom konstitutsionnom zakonodatel'stve // Pravovedenie, 1969. № 4. S.36-41.

16. Mitskevich A.V. Sub'ekty sovetskogo prava. M.: Gosyuridizdat, 1962.-211s.

17. Yu.S.Shemshuchenka. Konstitutsiyne pravo Ukraïni. Akademichniy kurs: Pidruchnik: U 2t. - T.2 / Za zagal'noyu redaktsicyu Yu.S.Shemshuchenka. - K.: TOV «Vidavnitstvo «Yuridichna dumka», 2008. - 800s.

18. Marchenko M. N. Problemy teorii gosudarstva i prava: ucheb. - M.: TK Velbi, Izd-vo Prospekt, 2007. - 768s. 